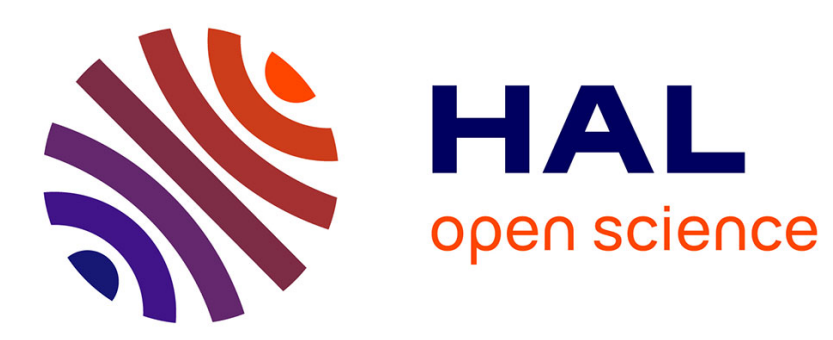

\title{
Structure and Dynamics of Exopolymers in an Intertidal Diatom Biofilm.
}

Lucas J. Stal, Christian Défarge

\section{To cite this version:}

Lucas J. Stal, Christian Défarge. Structure and Dynamics of Exopolymers in an Intertidal Diatom Biofilm.. Geomicrobiology Journal, 2005, 22 (7-8), pp.341-352. 10.1080/01490450500248721 . hal$00023494 \mathrm{v} 2$

\section{HAL Id: hal-00023494 \\ https://hal-insu.archives-ouvertes.fr/hal-00023494v2}

Submitted on 20 Apr 2009

HAL is a multi-disciplinary open access archive for the deposit and dissemination of scientific research documents, whether they are published or not. The documents may come from teaching and research institutions in France or abroad, or from public or private research centers.
L'archive ouverte pluridisciplinaire HAL, est destinée au dépôt et à la diffusion de documents scientifiques de niveau recherche, publiés ou non, émanant des établissements d'enseignement et de recherche français ou étrangers, des laboratoires publics ou privés. 


\title{
Erratum to
}

\section{Structure and dynamics of exopolymers in an intertidal diatom biofilm}

\section{[Geomicrobiology Journal 22: 341-352, 2005 ]}

\author{
Lucas J. Stal ${ }^{1 *}$ and Christian Défarge ${ }^{2}$ \\ ${ }^{1}$ Netherlands Institute of Ecology-KNAW, Department of Marine Microbiology, P.O.Box 140, \\ NL-4400 AC Yerseke, the Netherlands \\ ${ }^{2}$ Institut des Sciences de la Terre d'Orléans, UMR 6113 CNRS-University of Orléans, 45067 \\ Orléans cedex 2, France
}

Running head : Exopolymer in a diatom biofilm

*Corresponding author: e-mail: 1.stal@nioo.knaw.nl 
The Publisher regrets that bar markers were unfortunately cut from micrographs in Figures 2 to 5 , so the legends of these figures were not understandable by the readers. Please find new legend figures below.

FIG. 2. Cryo-FEG-SEM images of the sediment surface of the core incubated in the light and exposed to the air. Image width is approximately: (a) $0.24 \mathrm{~mm}$; (b) $100 \mu \mathrm{m}$; (c) $80 \mu \mathrm{m}$; (d) 5 $\mu \mathrm{m}$; (e) $10 \mu \mathrm{m}$; (f) $7.5 \mu \mathrm{m}$; (g) $25 \mu \mathrm{m}$; (h) $9 \mu \mathrm{m}$. See text for explanations.

FIG. 3. Cryo-FEG-SEM images of the sediment surface of the core incubated in the light and immersed. Image width is approximately: (a) $0.24 \mathrm{~mm}$; (b) $75 \mu \mathrm{m}$; (c) $7 \mu \mathrm{m}$; (d) $5.5 \mu \mathrm{m}$; (e) 8 $\mu \mathrm{m}$; (f) $6.5 \mu \mathrm{m}$; (g) $25 \mu \mathrm{m}$; (h) $10 \mu \mathrm{m}$. See text for explanations.

FIG. 4. Cryo-FEG-SEM images of the sediment surface of the core incubated in the dark and exposed to the air. Image width is approximately: (a) $0.27 \mathrm{~mm}$; (b) $140 \mu \mathrm{m}$; (c) $0.24 \mathrm{~mm}$; (d) $10 \mu \mathrm{m}$; (e) $25 \mu \mathrm{m}$; (f) $27 \mu \mathrm{m}$; (g) $6 \mu \mathrm{m}$; (h) $75 \mu \mathrm{m}$. See text for explanations.

FIG. 5. Cryo-FEG-SEM images of the sediment surface of the core incubated in the dark and immersed. Image width is approximately: (a) $0.24 \mathrm{~mm}$; (b) $9 \mu \mathrm{m}$; (c) $43 \mu \mathrm{m}$; (d) $20 \mu \mathrm{m}$; (e) 50 $\mu \mathrm{m}$; (f) $75 \mu \mathrm{m}$; (g) $10 \mu \mathrm{m}$; (h) $5 \mu \mathrm{m}$. See text for explanations. 